\title{
Activity of inhibit the cell cycle and induct apoptosis in HeLa cancer cell with combination of Sabrang onion (Eleutherine palmifolia (L.) Merr) and Starfruit Mistletoe (Macrosolen cochinchinensis (Lour.) Tiegh)
}

Roihatul Mutiah $^{1 *}$, Anik Listiyana ${ }^{2}$, Arief Suryadinata ${ }^{1}$, Rahmi Annisa $^{1}$, Abdul Hakim $^{1}$, Wirda Anggraini ${ }^{1}$, Retno Susilowati ${ }^{3}$

${ }^{1}$ Department of Pharmacy, Faculty of Medical and Health Sciences, Maulana Malik Ibrahim State Islamic University Malang, Malang, Indonesia. ${ }^{2}$ Department of Medical Education, Faculty of Medical and Health Sciences, Maulana Malik Ibrahim State Islamic University Malang, Malang, Indonesia. ${ }^{3}$ Department of Biology, Faculty of Sciences and Technology, Maulana Malik Ibrahim State Islamic University Malang, Malang, Indonesia.

\section{ARTICLE INFO \\ Received on: 03/07/2018 \\ Accepted on: 20/09/2018 \\ Available online: $31 / 10 / 2018$}

\section{Key words:}

Eleutherine palmifolia

(L.) Merr, Macrosolen

cochinchinensis (Lour.)

Tiegh, anti-cancer, HeLa

cervical cancer cell

\begin{abstract}
The combination of Eleutherine palmifolia (L.) Merr (EP) and Macrosolen cochinchinensis (Lour.) Tiegh (MC) extracts has been proven an empirically potential cure for cancer. The aims of this research were to prove scientifically the anticancer potential of the combination of EP and MC as well as its effects on the cell cycle and the apoptosis of HeLa cancer cell. The MTT method was used to measure cytotoxic effects. The effect of inhibition of cell cycle and induction of cell apoptosis was measured by the flow cytometry method. The results showed that the combination of EP and MC gives an induction of apoptosis effect of HeLa cancer cell through inhibition of cell cycle in the G0-G1, $\mathrm{S}$, and G2/M phases synergistically until it is synergist strong. Therefore, the combination of EP and MC can be recommended as a candidate drug for cancer therapy.
\end{abstract}

\section{INTRODUCTION}

Cervical cancer is a type of cancer that contributes greatly to the mortality rate of cancer patients, especially women. This type of cancer is the second most common cancer of the women with an estimated 445,000 new cases in 2012 or about $84 \%$ of new cases worldwide (Torre et al., 2015; WHO, 2013). Cervical cancer is caused by sexually transmitted infections with the type of HPV virus (Human Papilloma Virus).

There are many types of cancer treatment. The most common type of cancer treatments is surgery, radiotherapy, and

${ }^{*}$ Corresponding Author

Roihatul Mutiah, Department of Biology, Faculty of Sciences and Technology, Maulana Malik Ibrahim State Islamic University Malang, Malang, Indonesia.E-mail: retno.susilowati@bio.uin-malang.ac.id chemotherapy but the treatments not obtained optimum results. Each of these therapies has some side effects that tend to endanger the patient (Arruebo et al., 2011). The frequent failure of cancer treatment, mainly through chemotherapy is due to the low selectivity of anticancer drugs against normal cells. In addition, the failure of chemotherapy is also caused by cancer cell resistance to chemotherapeutic agents. The phenomenon of such resistance carry consequences on increasing therapeutic dose (Tacar et al., 2013). It causes a phenomenon of multi-drug resistance (MDR) that can improve therapeutic toxicity (Moitra, 2015).

Therapy using herbal medicine is one solution to the phenomenon of the MDR. Previous research has shown that herbal medicines derived from natural materials have lower side effects than modern medicine (Yuan et al., 2016). Eleutherine palmifolia (L.) Merr (EP) is known as Sabrang or Dayak onion. This is a traditional medicinal plant from Kalimantan and empirically has 
been used by the community to treat various diseases, one of them is cancer. Some research has shown that the extract is able to inhibit cancer growth through inhibition of cell growth cycles and induction of the cell apoptosis. It was reported that ethanol and ethyl acetate fractions of Sabrang onion were able to inhibit the cell cycle of G1-G2 phase by $40.88 \%$ (Fitri and Suwarso, 2014). It was also reported that the ethanol fraction of Sabrang onion was able to suppress the growth of HT29 colon cancer with mutant expression of p53 (Yusni et al., 2008).

Not much different from Sabrang onion, Starfruit Mistletoe with the scientific name Macrosolen cochinchinensis (Lour.) Tiegh (MC) is also a potential anticancer agent. Starfruit Mistletoe is a native Indonesian plant that only grows in Kalimantan (Febrinda, 2014). Empirical data show that this plant for many years has been exploited by the people of Kalimantan as a cancer drug. It was reported that Starfruit Mistletoe leaf extract is antioxidant as evidenced by $D P P H$ free radical scavenging activity (Rahman et al., 2012). This is supported by the results of anticancer in vitro test showed that the Starfruit Mistletoe water extract of has a strong anticancer activity against T47D breast cancer cells by apoptosis induction and cell cycle resistance in G0-G1, S, and G2-M (Mutiah et al., 2017).

Based on empirical data, it was known that the combination of Sabrang onion (EP) and Starfruit Mistletoe (MC) can help to cure cancer patients and has been proven that many people were helped by this herb. Therefore, it was important to do a scientific proof of the potential of the combination as an anticancer drug. The aims of this research were to test the anticancer potential of the combination of EP and MC as well as to test its effects on the cell cycle and the apoptosis of HeLa cancer cell.

\section{RESEARCH METHODS}

\section{Test materials}

Plant materials used in this research were Macrosolen cochinchinensis (Lour.) Tiegh (MC) and Eleutherine palmifolia (L.) Merr (EP) obtained from Malang city of East Java. Determination of both plants was done in the Indonesian of Sciences Institute (LIPI) in Purwodadi, East Java. Specimen number 20170304 and 20170305 were stored in a Laboratory of Pharmacognosy, Pharmacy Department, Faculty of Medicine and Health Sciences, Maulana Malik Ibrahim State Islamic University, Malang.

\section{Materials for extraction}

The solvent used for the maceration extraction phase was $70 \%$ ethanol.

\section{Materials for cell culture}

The cancer cell to be used in this research was the HeLa cervical line cell. The cells were obtained from the Cancer Chemoprevention Research Center (CCRC), Faculty of Pharmacy, Gadjah Mada University and from Prof. Masasi Kawaichi, Laboratory of Gene Function in Animal, Graduate School of Biological Science, Nara Institute of Science and Technology. HeLa cells in the Rosewell Park Memorial Institute (RPMI) medium was added with $10 \%$ of heat-inactivated fetal bovine serum (FBS) (PAA Laboratories), 1\% v/v penicillin-streptomycin
(Nacalay Tesque), and 1.0 mM L-glutamine (Nacalay Tesque). Then, the cells were cultured in an incubator at $5 \% \mathrm{CO}_{2}$ and $95 \%$ $\mathrm{O}_{2}$ temperature of $37^{\circ} \mathrm{C}$.

\section{The cytotoxic test materials}

Dimethyl sulfoxide (DMSO) was used to dissolve the extracts of EP and MC. The concentration used in this research was a maximum of $1 \%$ in the culture medium. $0.025 \%$ trypsin in culture medium was used to harvest cells. Phosphate buffer saline (PBS) was used as a buffer solution. 3-(4,5-dimethylthiazole-2yl)-2,5-diphenyltetrazolium bromide (MTT) was used as reagents that react with the succinate dehydrogenase enzyme in the cell.

\section{Extraction}

Eleutherine palmifolia (EP) and Macrosolen cochinchinensis (Lour.) Tiegh (MC) were taken from Kalimantan, Indonesia. The part of the plant used in the EP is the part of the tuber while the $\mathrm{MC}$ is the part of the leaf. In each part, sample preparation is done by sorting, washing, drying (temperature $45^{\circ} \mathrm{C}$ ), and pollinated with a smooth degree. Each powder was inserted into Erlenmeyer and ethanol 96\% solvent was added with a ratio of 1:20. Then extracted using ultrasonication assisted extraction (UAE) for 2 minutes with three replications. The filtrate of $C$. cinerariifolium leaves from the UAE was evaporated by a solvent using rotary evaporator at a temperature of $50^{\circ} \mathrm{C}$ to produce a thick extract. The thick leaf extract is concentrated using an oven at $40^{\circ} \mathrm{C}$ until the extract texture becomes concentrated. Then, the yield is calculated by the formula:

$$
\text { Rendemen }=\frac{\text { extract weight }}{\text { simplicia weight }} \times 100 \%
$$

In this research, $200 \mathrm{~g}$ of Eleutherine palmifolia (EP) powder produces $16.0893 \mathrm{~g}$ of extracts so that the EP yield was $8.04 \%$ and $200 \mathrm{~g}$ of Macrosolen cochinchinensis (Lour.) Tiegh (MC) powder produces $30.46 \mathrm{~g}$ of extracts so that the MC yield was $15.23 \%$.

\section{Moisture content analysis}

In the quality control, the extract used moisture content analysis. The extract obtained is then analyzed for water content using HC103 halogen moisture analyzer. Samples of approximately $0.500 \mathrm{~g}$ are inserted into the sample pan, then $\%$ Moisture Content will appear. In each extract section, Moisture Content Analysis is carried out until the water content is less than $10 \%$. In this study, the moisture content of EP and MC extracts was obtained respectively: $5.23 \% \pm 0.25 \%$ and $6.45 \% \pm 0.32 \%$.

\section{Test anticancer activity by MTT method}

The suspension of HeLa cervical cancer cells, each of $100 \mu \mathrm{l}$ with a density of $3 \times 10^{4}$ cells $/ 100 \mu \mathrm{l}$ of medium was distributed into wells at 96-well plate and incubated for 24 hours. After incubation, $100 \mu \mathrm{l}$ test solution was added into the wells at various concentration series. The test solution used was a single EP extract. The other test solution was a single MC extract. As a cell control, $100 \mu \mathrm{l}$ culture medium was added into the well containing $100 \mu \mathrm{l}$ cell suspension and as a solvent control $100 \mu \mathrm{l}$ DMSO was added into the well containing $100 \mu$ culture medium and $100 \mu \mathrm{l}$ cell suspension with delusions corresponding to the 
Table 1. The average of cell viability percentage and $\mathrm{IC}_{50}$ crude of $\mathrm{EP}$ and $\mathrm{MC}$ extracts value on HeLa cancer cells.

\begin{tabular}{|c|c|c|c|c|c|c|c|c|c|}
\hline \multirow{2}{*}{ No } & \multirow{2}{*}{ Extract } & \multicolumn{7}{|c|}{ Average $\%$ Hela cell viability $\pm \mathrm{SD} *$ at test concentration $(\mu \mathrm{g} / \mathrm{ml})$} & \multirow{2}{*}{$\mathrm{IC}_{50}(\mu \mathrm{g} / \mathrm{ml}) \pm \mathrm{SD}$} \\
\hline & & 7813 & 15625 & 3125 & 625 & 125 & 250 & 500 & \\
\hline$\overline{1}$ & $\mathrm{MC}$ & $0909+045$ & $0954+089$ & $0453+078$ & $8500+125$ & $8541+245$ & $3822+060$ & $1876+055$ & $21772+0034$ \\
\hline 2 & FP & $6641+056$ & $7705+064$ & $5638+032$ & $5600+098$ & $3250+043$ & $745+076$ & $601+156$ & $4036+005$ \\
\hline
\end{tabular}

*Mean value and deviation with three replications

delusions of the test solution concentration, and then incubated for 24 hours in incubator with $5 \% \mathrm{CO}_{2}$ and $95 \% \mathrm{O}_{2}$ flow. At the end of incubation, the culture medium was removed and $10 \mu \mathrm{l}$ of MTT solution ( $5 \mathrm{mg} / \mathrm{ml}$ PBS) was added, and the medium was replaced with $190 \mu \mathrm{l}$ of complete RPMI 1640 medium. Then, cells were incubated for 3-4 hours. The MTT reaction was discontinued the addition of an SDS stopper reagent $(100 \mu \mathrm{l})$. The microplate was then wrapped in a tissue and incubated for a night at room temperature and dark room. Living cells react with MTT to form a purple color. Test results were read with ELISA reader at $595 \mathrm{~nm}$ wavelength (Mutiah, 2014). The test results of single therapy of Starfruit Mistletoe extract and Sabrang onion extract on HeLa cancer cells with MTT method is presented in Table 1.

\section{Analysis of cell cycle with flow cytometry}

In this cell cycle analysis used Propidium Iodide dye (PI). This dye can be used to analyze the number of DNA sets in each cell. Cells of $5 \times 10^{5}$ cells/wells were planted in a 6 -well plate and then incubated until normal again. Cells were treated with DMSO solvent $(0.25 \%)$ and active isolates on $\mathrm{IC}_{50}$. The cells were then reincubated for 24 hours. At the end of the incubation time, the medium was taken and transferred into a tube and centrifuged (2,000 rpm, 3 minutes) and then, the supernatant was removed. At the well that has been taken it medium, PBS was added and PBS were transferred to the same microtube from one treatment, then centrifuged and the supernatant was discarded. This stage was repeated once more and the cells were harvested with trypsin. Cells were transferred into the same microtube and then centrifuged (2,000 rpm, 3 minutes). The rest of the harvesting cells that are on the well were rinsed with PBS and centrifuged again, then the PBS was discarded. The cell sediments in the microtube were then fixed with $70 \%$ ethanol, $-20^{\circ} \mathrm{C}$, incubated for 30 minutes at room temperature or overnight at $4^{\circ} \mathrm{C}$, then centrifuged $(371 \mathrm{~g}$; 3 minutes). The cell sediment was washed with PBS twice and then was added with PI reagents with caution, and immediately homogenized. The microtube containing the cell suspension was wrapped in aluminum foil and incubated in a $37^{\circ} \mathrm{C}$ water bath for 20 minutes. The cell suspension was homogenized again and transferred into a flow cytometer tube using a nylon filter, then ready to be analyzed with a flow cytometer (Mutiah et al., 2018b).

\section{Analysis of induced apoptosis cell with flow cytometry}

Cells of $5 \times 10^{5}$ cells/wells were planted in a 6-well plate, and then the cells were incubated until normal again. Cells were treated with DMSO solvent $(0.25 \%)$ and active isolates. The cells were then reincubated for 24 hours. At the end of the incubation time, the medium was taken and transferred into a tube and centrifuged (371 g; 3 minutes) and then the supernatant was removed. At the well that has been taken it medium, PBS was added and PBS was transferred to the same microtube from one treatment, then centrifuged and then the supernatant layer was removed. This stage was repeated once more and the cells were harvested with trypsin. Cells were transferred into the same microtube and then centrifuged ( $371 \mathrm{~g} ; 3$ minutes). The rest of the harvesting cells that were on the well were rinsed with PBS and centrifuged again, and then the PBS was discarded. The sediment was added with PIAnnexin $\mathrm{V}$ reagents with caution and immediately homogenized. The microtube containing the cell suspension was wrapped in aluminum foil and incubated in a $37^{\circ} \mathrm{C}$ of water bath for 5 minutes. The cell suspension was homogenized again and transferred into a flow cytometer tube using a nylon filter, and then ready to be analyzed with a flow cytometer (Mutiah et al., 2018b).

\section{Data analysis}

The data obtained in form of absorbance of each well converted into living cell percentage:

Percentage $(\%)$ of living cell $=\frac{(\text { treatment abs. }- \text { media control abs. })}{(\text { cell control abs. }- \text { media control abs. })} \times 100 \%$

Description: Abs: absorbance

Percentage of living cells was calculated to obtain an $\mathrm{IC}_{50}$ value that is the concentration causing inhibition of growth as much as $50 \%$ of the cell population so that the cytotoxic potential can be known. The value of $\mathrm{IC}_{50}$ was determined by probit analysis [Statistic Product and Service Solution (SPSS) 16.0 for Windows].

Combined cytotoxicity was determined by calculating the interaction index between the extract of Starfruit Mistletoe (MC) and the Sabrang Onion Extract (EP), using the equation:

$$
\text { Combination Index/CI = (D) } 1 /(\mathrm{Dx}) 1+\text { (D) } 2 /(\mathrm{Dx}) 2
$$

D1 and D2 were the sample concentrations used in the combination treatment. (Dx) 1 and (Dx) 2 were single concentrations which can produce the effect, as big as given by the combined treatment (Reynold and Maurer, 2005). The resulting CI or Combination Index obtained was interpreted as follows: $<0.1$ very strong synergistic effect, $0.1-0.3$ strong synergistic effect, $0.3-0.7$ synergistic effect, $0.7-0.9$ mild-moderate synergistic effect, $0.9-1.1$ close to the additive effect, 1.1-1.45 mild-moderate antagonist effect, 1.45-3.3 antagonistic effect, $>3.3$ strong-very strong antagonistic effect (Mutiah et al., 2018a).

\section{RESULTS AND DISCUSSION}

\section{Effect of E. palmifolia and M. cochinchinensis combination on HeLa cancer cells}

The aims of this research were to explain the effect of giving combination Sabrang onion (EP) and starfruit mistletoe (MC) extracts on anticancer activity, cell cycle, and HeLa cervical cancer cell-induced apoptosis. The anticancer potential of EP and $\mathrm{MC}$ combination on HeLa cancer cells was known through MTT test (3-4,5-dimethilthiazole-2-il)-2,5-diphenyltetrazolium). 
Table 2. HeLa cell viability percentage due to the treatment of EP and MC extracts combination.

\begin{tabular}{ccccc}
\hline \multirow{2}{*}{$\mathbf{E P}(\boldsymbol{\mu g} / \mathbf{m l})$} & \multicolumn{4}{c}{${ }^{*}$ Cell viability\% } \\
\cline { 2 - 5 } & \begin{tabular}{c} 
MC \\
\cline { 2 - 5 }
\end{tabular} & $\begin{array}{c}\text { MC } \\
\mathbf{( 2 3 . 3} \boldsymbol{\mu g} / \mathbf{m l})\end{array}$ & $\begin{array}{c}\text { MC } \\
\mathbf{( 6 9 . 9} \mathbf{\mu g} / \mathbf{m l})\end{array}$ & $\begin{array}{c}\text { MC } \\
\mathbf{( 9 3 . 2 8} \boldsymbol{\mu g} / \mathbf{m l})\end{array}$ \\
\hline 5.65 & $71.43 \pm 9.86$ & $82.77 \pm 0.52$ & $77.56 \pm 1.66$ & $63.6 \pm 2.03$ \\
11.31 & $67.036 \pm 9.57$ & $81.75 \pm 2.4$ & $75.29 \pm 1.48$ & $60.18 \pm 2.79$ \\
16.96 & $68.14 \pm 10.6$ & $78.57 \pm 1.89$ & $73.89 \pm 3.01$ & $79.34 \pm 2.4$ \\
22.62 & $56.37 \pm 6.35$ & $75.00 \pm 4.27$ & $74.08 \pm 4.27$ & $78.9 \pm 2.21$ \\
\hline
\end{tabular}

*Average \pm Standard Deviation, $n=3$

Table 3. Analysis of synergism effect on the treatment of EP and MC extracts combination on HeLa Cell Line.

\begin{tabular}{|c|c|c|c|c|}
\hline \multirow[b]{2}{*}{$\mathbf{E P}(\mu \mathrm{g} / \mathrm{ml})$} & \multicolumn{4}{|c|}{ Combination index } \\
\hline & $\begin{array}{c}\text { MC } \\
(23.3 \mu \mathrm{g} / \mathrm{ml})\end{array}$ & $\begin{array}{c}\text { MC } \\
(46.6 \mu \mathrm{g} / \mathrm{ml})\end{array}$ & $\begin{array}{c}\mathrm{MC} \\
(69.9 \mu \mathrm{g} / \mathrm{ml})\end{array}$ & $\begin{array}{c}\text { MC } \\
(93.28 \mu \mathrm{g} / \mathrm{ml})\end{array}$ \\
\hline 5.65 & 0.81 & 6.39 & 4.91 & 1.13 \\
\hline 11.31 & 0.51 & 6.07 & 3.86 & 0.75 \\
\hline 16.96 & 0.64 & 4.31 & 3.36 & 8.70 \\
\hline 22.62 & 0.15 & 2.87 & 3.58 & 8.52 \\
\hline
\end{tabular}

MC: Extract of Macrosolen cochinchinensis (Lour.) Tiegh

EP: Extract of Eleutherine palmifolia (L.) Merr

The combined dosage used was 16 doses under $\mathrm{IC}_{50}$. The results of the effectiveness test of EP and MC combination on HeLa cancer cells were compared with single therapy, so it can be known the efficacy of the combination preparation compared to the single preparation. Previously, we needed to test the cytotoxic activity of single preparation to determine $\mathrm{IC}_{50}$. The result of a single cytotoxic test of EP and MC has been written in Table 1.

Once the $\mathrm{IC}_{50}$ of each extract is known, the test on the combination of both extracts on HeLa cancer cells is performed. The combination test was performed with each of 16 concentrations series below the concentration of $\mathrm{IC}_{50}$. The purpose of the dosage used under $\mathrm{IC}_{50}$ is to obtain a dose combination which has a high anticancer effect on low doses so it is expected to reduce side effects and decrease toxicity on normal cells.

Of the 16 combinations tested showed that the combination of EP and MC gave a very strong synergistic effect until the antagonist was very strong against the inhibition of growth of HeLa cells (Table 3). The combination of doses having a strong synergistic effect was the dose of EP $22.62 \mu \mathrm{g} / \mathrm{ml}$ and MC $23.3 \mu \mathrm{g} / \mathrm{ml}$ with Combination Index of 0.15 . The combination of doses that have the synergistic effect was a combination of doses of $23.3 \mu \mathrm{g} / \mathrm{ml} \mathrm{MC}$ and $11.31 \mu \mathrm{g} / \mathrm{ml} \mathrm{EP;} 23.3 \mathrm{ug} / \mathrm{ml} \mathrm{MC}$ and 16.96 $\mathrm{ug} / \mathrm{ml}$ EP. The dosage may be recommended for further research. The test result of the MTT method of EP and MC combination was presented in Tables 2 and 3. The graph of the combination isobologram was shown in Figure 1 below:

$10^{4}$ cells/wells were planted on well plates, incubated for 24 hours in RPMI medium without or with the combination treatment of EP and MC with a predetermined concentration. Cell viability was determined by the MTT method. The results of this analysis were the representations of two different experiments, each with three replications.

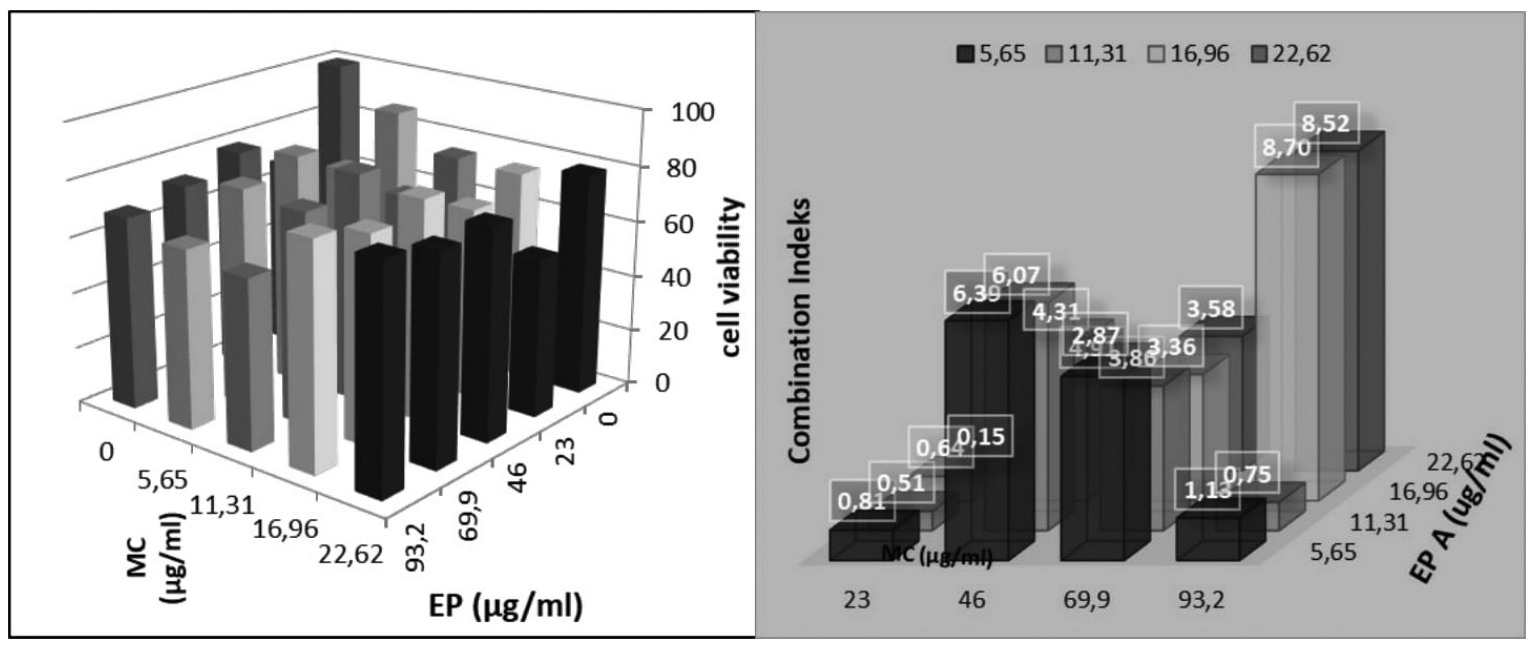

Figure 1. The effect of the combination of E.palmifolia (EP) and M. cochinchinensis (MC) treatment on the growth of HeLa cervical cancer cells. (A) The effect of combination treatment on cell viability. (B) Combination Index (CI) from a combination of EP and MC. 
C
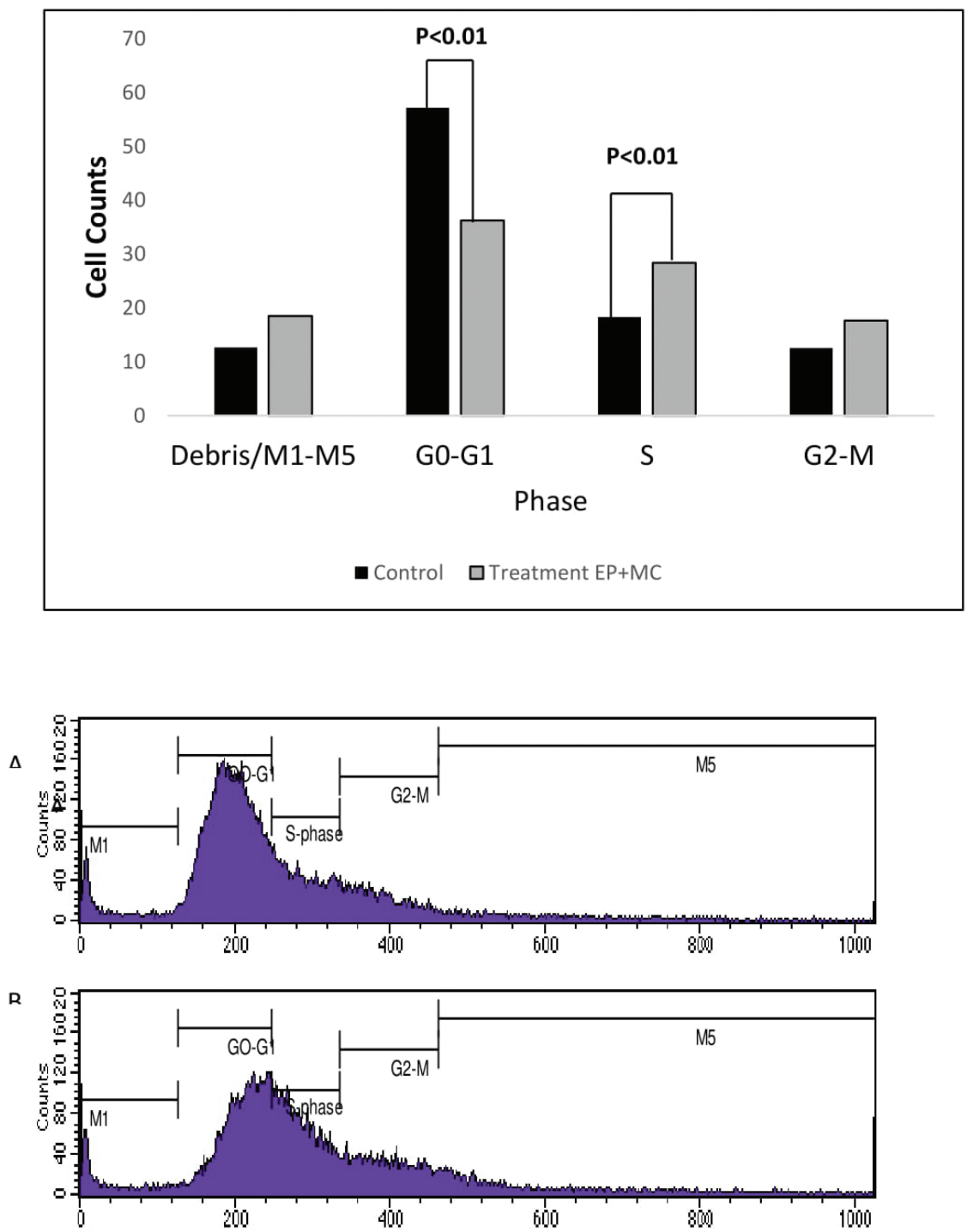

Figure 2. Effects of induction of cell death and changes in distribution in the cell cycle phase of cancer cells HeLa cervical treatment (A) Control with DMSO solvent (B) Combination $\mathrm{EP}$ and $\mathrm{MC}$ at the dosage of $\mathrm{IC}_{50}$. HeLa cells as much as $5 \times 10^{5}$ cells/well, incubated for 24 hours and given a combination treatment on $\mathrm{IC}_{50}$. The profile distribution of each phase (G1, M, S, and $\left.\mathrm{G} 2 / \mathrm{M}\right)$ in the cell cycle was analyzed using flow cytometry with Propidium Iodide (PI) painting.

\section{Analysis Results of HeLa cell cycle regulation due to the treatment of EP and MC combination}

Observation of the HeLa cell cycle due to of the combination treatment of EP and MC. This aims to determine whether the combination of EP and MC can direct the HeLa cancer cell cycle to the checkpoint phase. Checkpoint control plays a role in regulating abnormalities at every stage of the cycle cell, which serves to prevent the cells from entering the next stage in the case of DNA damage. In cancer cells, the inability of checkpoint control occurs in the cell cycle stage so that discontinued DNA replication to mitosis despite DNA damage. This causes the cancer cells to proliferate uncontrollably (Worthley et al., 2007).

Analysis of cell cycle was done by fluorescence-activated cell sorting method using Propidium Iodine (PI) probe. Figure 3 shows that the combination treatments of EP and MC at $\mathrm{IC}_{50}$ doses can inhibit regulation of cell cycle marked by the increasing accumulation of cell in a G2-M phase of $17.66 \%$ and a synthesis of $28.35 \%$ following depletion of G0-G1 phase accumulation compared to control cells. The M1-M5 cycle shows the number of dead cells. The treatment of the number of dead cells combination shows the increase of $18.47 \%$ (Fig. 3). The statistical test results indicate that the depletion of G0-G1 phase accumulation differs significantly to control $(p<0.001)$. The result of the cell cycle regulation test is presented in Figure 2.

\section{Analysis of HeLa Cell Apoptosis Induction on the Treatment of EP and MC Combination}

Observation of apoptosis induction was performed to determine the cause of cell death both in apoptosis, and necrosis. Flow cytometry method is able to distinguish living cells, early 

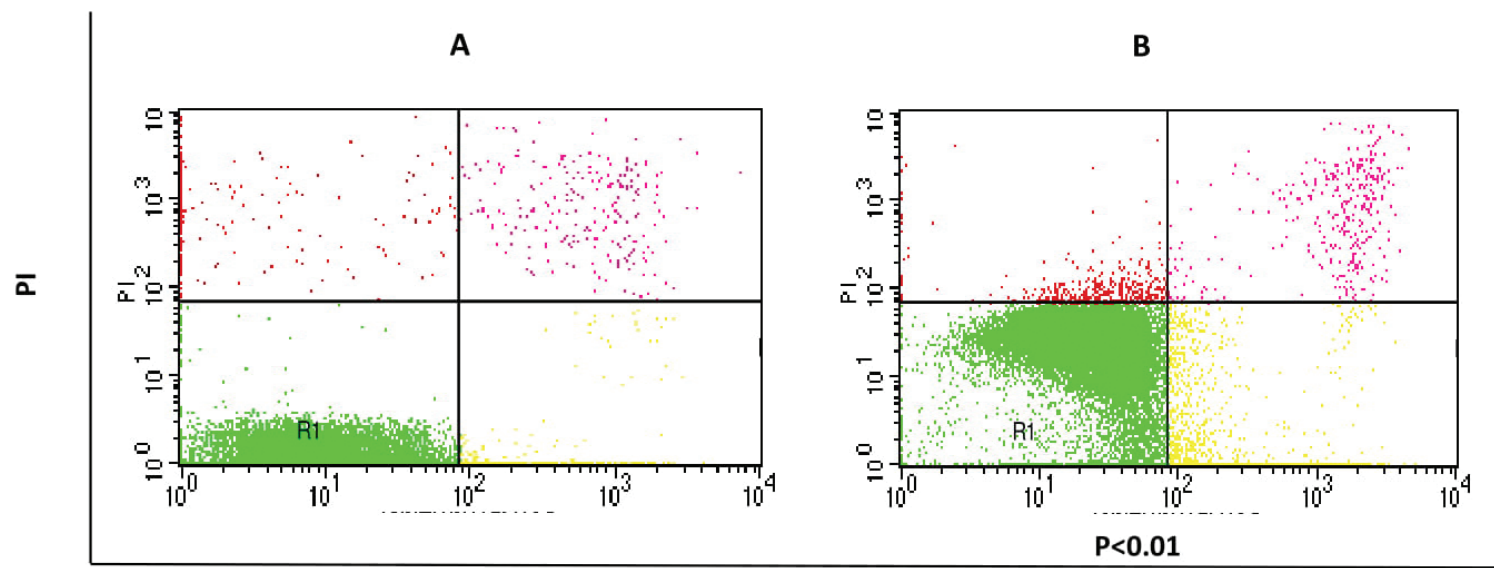

Annexin-V

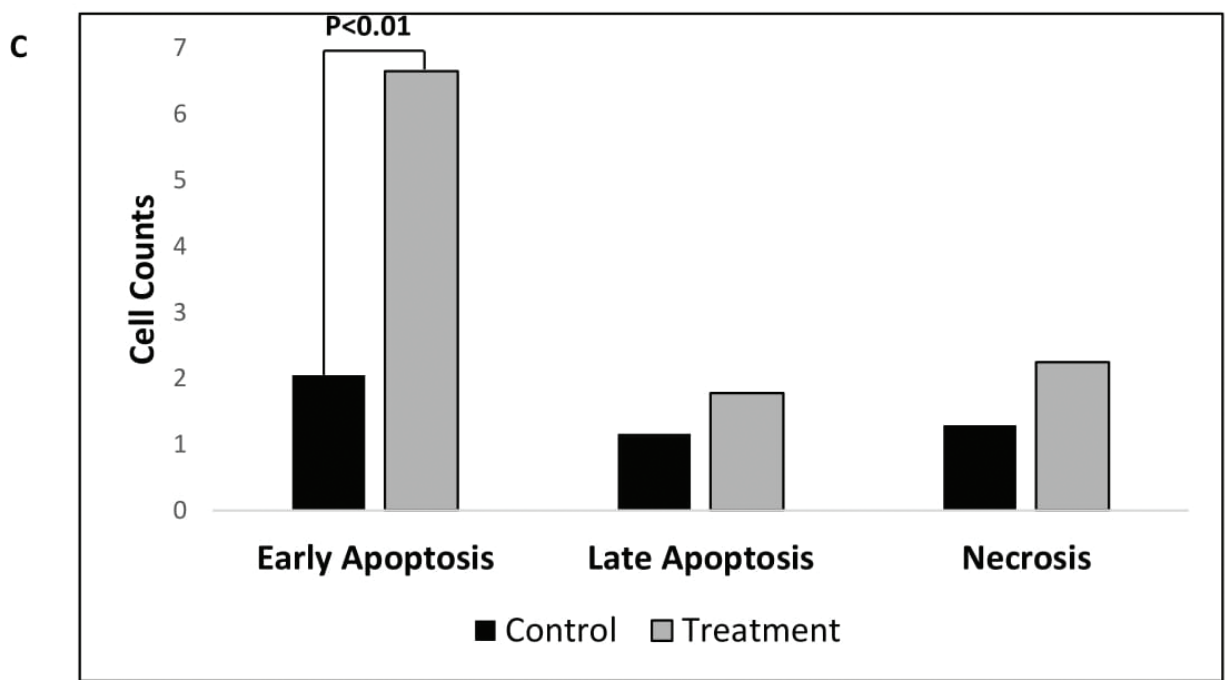

Figure 3. Shows the results of cell distribution and analysis of cell death induction/cell quest using Flow cytometry method (A) HeLa cells control method, (B) Treatment of EP and MC combination on HeLa cells, and (C) Comparison graph of viable, apoptosis and necrosis cell.

apoptosis, late apoptosis and necrosis because the Annexin V and PI reagents work selectively in binding the intact or fragmented cells.

The treatment of EP and MC combination on HeLa cervical cancer cells causes cells to increase apoptosis 9.19\% compared to control treatment (DMSO) (Fig. 3). Based on statistical test results it showed that the increase of apoptosis induction was significantly different with control $(p<0.001)$. Increased apoptosis of these cells is in line with increasing cell accumulation in the G0 phase. The result of apoptosis induction test using flow cytometry is presented in Figure 3 below:

Flavonoid and polyphenol compounds have been studied for their effectiveness as chemoprevention agents that have a variety of activities and functional targets either as blocking, suppressing, or anti-metastatic/anti-invasive cancer cells. Eleutherine palmifolia (L.) Merr (EP) contains flavonoid isoliquiritigenin compounds. These compounds have been shown to have chemoprevention effects through apoptosis induction and are able to inhibit metastases cancer cell through inhibition of neoangiogenesis in VEGF/VEGFR-2 Signaling Pathway (Wang et al., 2013). Several previous studies have shown that isoliquiritigenin compounds have chemoprevention activity on B16 melanoma cells (Iwasitha et al., 2000), colon cancer cells (Takashi et al, 2004), breast cancer cells (Wang, et al., 2013), and squamous cell (Hou et al., 2017). Another flavonoid compound also found in Dayak onion bulbs was oxyresveratrol compounds.

Macrosolen cochinchinensis (Lour.) Tiegh (MC) contains flavonoids, especially quercetin. These compounds were known to play the role of capturing free radicals or functioning as a natural antioxidant. Such antioxidant activity allows flavonoids to capture or neutralize free radicals (such as ROS or RNS which are one of the causes of oncogenesis) associated with phenolic $\mathrm{OH}$ groups. Flavonoids in mango mistletoe, quercetin, which was a compound that can be used as an anticancer also have the ability as anti-proliferation. Quercetin may act as an anticancer to cell cycle regulation because it can suppress p53 protein mutant expression in cell cycle control by stimulating an arrested or apoptotic cell so there is no excessive cell proliferation (Gibellini et al., 2011). Quercetin is also a compound that can inhibit neutrophil migration since quercetin may inhibit the COX-2 enzyme. COX-2 enzyme mediates arachidonic acid conversion into prostaglandin and leukotriene which is a chemical mediator of neutrophil migration (Xiao et al., 2011). 


\section{CONCLUSION}

Combination of Eleutherine palmifolia (L.) Merr (EP) and Macrosolen cochinchinensis (Lour.) Tiegh (MC) extracts has a strong synergistic effect on the EP $22.62 \mu \mathrm{g} / \mathrm{ml}$ and MC 23.3 $\mathrm{ug} / \mathrm{ml}$ doses with a combination index of 0.15 . The combination of doses giving synergistic effect was a combination of MC 23.3 $\mu \mathrm{g} / \mathrm{ml}$ and EP 11.31 dose; MC $23.3 \mu \mathrm{g} / \mathrm{ml}$ and EP $16.96 \mu \mathrm{g} / \mathrm{ml}$ dose. Combination of EP and MC extracts affects the cell cycle inhibition in G0-G1, G2/M, and S (synthesis) phase. It can also increase the apoptosis of HeLa cancer cell.

\section{ACKNOWLEDGMENT}

The Researcher delivers the gratitude to the Competitive Research Grant Fund of the Directorate General of Islamic Higher Education of the Republic of Indonesia of 2017, so this research can be conducted well.

\section{CONFLICT OF INTEREST}

There is no conflict of interest in this study.

\section{REFERENCES}

Arruebo M, Vilaboa N, Gutierrez BS, Lambea J, Tres A, Valladares M, Farnandez AG. Assessment of the evolution of cancer treatment therapies. Cancers, 2011; 3:3279-330.

Febrinda AE, Yuliana ND, Ridwan E, Wresdiyati T, Astawan M. Hyperglycemic control and diabetes complication preventive activities of Bawang Dayak (Eleutherine palmifolia L. Merr.) bulbs extracts in alloxandiabetic rats. Int Food Res J, 2014; 21:1405-11.

Fitri Y, Suwarso E. Effects of inhibition cell cycle and apoptosis of sabrang onion extract (Eleutherine bulbosa (Mill.) Urb.) on breast cancer cells. Int J PharmTech Res, 2014; 6:1392-96.

Gibellini L, Pinti M, Nasi M, Montagna JP, De Biasi S, Cooper EL, Cossarizza A. Quercetin and cancer chemoprevention. Evid Based Complement Alternat Med, 2011; 201:1-15.

Hou C, Li W, Li Z, Gao J, Chen Z, Zhao X, Yang Y, Zhang $\mathrm{X}$, Song Y. Synthetic isoliquiritigenin inhibits human tongue squamous carcinoma cells through its antioxidant mechanism. Hindawi Oxid Med Cell Longev, 2017; 1:1-11.

Iwashita K, Kobori M, Yamaki K, Tsushida T. Flavonoids inhibit cell growth and induce apoptosis in B16 Melanoma 4A5 cells. Biosci Biotchnol Biochem, 2000; 64:1813-20.

Moitra K. Overcoming multidrug resistance in cancer stem cells. BioMed Res Int, 2015; 1:1-8.

Mutiah R. Pengembangan Fitofarmaka Antikanker Panduan Teknik Pengembangan Obat Herbal Indonesia Menjadi Fitofarmaka. Uin Maliki Press, 2014. ISBN: 978-602-1190-26-5 [Indonesian].

Mutiah R, Listiyana A, Indradmojo C, Griana TP, Dwi HH, Atmaja RR. Induction of apoptosis and phase-cell cycle inhibition of G0G1, S, G2-M of T47D breast cancer cells on treatment with ethyl acetate fraction of jackfruit parasite leaves (Macrosolen cochinchinensis). J Appl Pharma Sci, 2017; 7:138-43.
Mutiah R, Widyawaruyanti A, Sukardiman S. Calotropis gigantea leaf extract increases the efficacy of 5-fluorouracil and decreases the efficacy of doxorubicin in Widr colon cancer cell culture. J Appl Pharm Sci, 2018a; 8:51-6.

Mutiah R, Widyawaruyanti A, Sukardiman S. Calotroposid A: a glycosides terpenoids from calotropis gigantea induces apoptosis of colon cancer WiDr cells through cell cycle arrest G2/M and caspase 8 expression. Asian Pac J Cancer Prev, 2018b; 19:1457-64.

Rahman MM, Chowdhury MAU, Uddin ME, Islam AMT, Hossain MA. Macrosolen cochinchinensis (Lour.): anti-nociceptive and antioxidant activity. Asian Pac J Trop Biomed, 2012; 2:203-7.

Reynolds CP, Maurer BJ. Evaluating response to antineoplastic drug combinations in tissue culture models. Methods Mol Med, 2005; 110 : $173-83$.

Tacar O, Sriamornsak P, Dass CR. Doxorubicin: an update on anticancer molecular action, toxicity and novel drug delivery systems. J Pharm Pharmacol, 2013; 65:157-70.

Takahashi T, Takasuka N, Ligo M, Baba M, Nishino $H$, Tsuda H, Okuyama T. Isoliquiritigenin, a flavonoid from licorice, reduce prostaglandin $\mathrm{E}_{2}$ and nitric oxide, causes apoptosis, and suppress aberrant crypt foci development. Cancer Sci, 2004; 95:448-53.

Torre L, Bray F, Siegel R, Ferlay J, Lorte T, Jemal A. Global cancer statistics. CA Cancer J Clin, 2015; 62:87-108.

Wang Z, Wang N, Han S, Wang D, Mo S, Yu L, et al. Dietary compound isoliquiritigenin inhibits breast cancer neoangiogenesis via VEGF/VEGFR-2 signaling pathway. PLoS One, 2013; 8:1-14.

World Health Organization (WHO). WHO guidance note: comprehensive cervical cancer prevention and control: a healthier future for girls and women. WHO Press Geneva, Switzerland, 2013.

Worthley DL, Whitehall VL, Spring KJ, Leggett BA. Colorectal carcinogenesis: road maps to cancer. World J Gastroenterol, 2007; 13: 3784-91.

Xiao X, Shi D, Liu L, Wang J, Xie X, Kang T, Deng W. Quercetin suppresses cyclooxygenase-2 expression and angiogenesis through inactivation of P300 signaling. PLoS One, 2011; 6:1-10.

Yuan H, Ma Q, Ye L, Piao G. The traditional medicine and modern medicine from natural products. Molecules, 2016; 21:1-18.

Yusni MA, Metria IB, Budiani DR, Mudigdo A. Perbedaan Pengaruh Pemberian Fraksi Etanolik Bawang dayak (Eleutherine palmifolia L.Merr) dengan 5-Fluorouracil Terhadap Penghambatan Pertumbuhan Galur Sel Karsinoma Kolon HT29 dan Ekpresi p53 Mutan. Medical Faculty Universitas Sebelas Maret, 2008; 65-76 [Indonesian].

How to cite this article:

Mutiah R, Anik L, Arief S, Annisa R, Hakim A, Anggraini W, Susilowati R. Activity of inhibit of the cell cycle and induct apoptosis in HeLa cancer cell with combination of Sabrang onion (Eleutherine palmifolia (L.) Merr) and Starfruit Mistletoe Macrosolen cochinchinensis (Lour.) Tiegh extracts. J App Pharm Sci, 2018; 8(10): 122-128. 